\title{
A CONTRIBUTION TO THE MENTAL PATHOLOGY OF RACES IN THE UNITED STATES *
}

PEARCE BAILEY, M.D.

NEW YORK

To those who believe with Kraepelin that the disposition of a people finds expression in its mental diseases, it would seem that investigations of the mental pathology of peoples and races might lead to some information as to the general characteristics of the peoples concerned. The character and degree of intelligence, emotional stability, morale, tendencies to criminalism and to inebriety, might be revealed by these measures. Such information might well be more definite than indicated by the actual number of cases found, as for each case pronounced enough to be called a disease there would be many borderline ones of the same category showing the same general trends. An excessive distribution in any community of any particular type of diseașe might well indicate the general mental level and trend of that community.

Obvious difficulties stand in the way of investigations of this kind. Intensive surveys are necessarily restricted to small groups, and are limited in their general application. The general statistics have never been compiled in a manner to throw much light on the subject. The neuropsychiatric statistics of the army afford an opportunity to analyze a large group of all kinds of neuropsychiatric defects and disorders which existed in the representative manhood of the country from 1917 to 1919. It is the purpose of this paper to set forth the results of the analysis of these cases as far as they concern certain foreign-born and native-born races. ${ }^{1}$

From them it appears that, with the exception of epilepsy, certain communities and certain races in the United States display wide variations in the distribution of one or another form of nervous or mental disorders found among them. For example, according to the statistics, the negro exhibits a tendency toward mental defect and away from every other neuropsychiatric condition, while the native-born Scot shows a tendency away from mental defect and toward alcoholism and certain other neuropsychiatric conditions. The widest variations occur in reference to mental defect and inebriety, and the chief value of this study concerns the variations found in respect to these two conditions.

* Read at the Forty-Seventh Annual Meeting of the American Neurological Association, Atlantic City, N. J., June, 1921.

1. The classification of races made use of is taken from the "Dictionary of Races," prepared under the direction of the Department of Immigration and published in 1910. 
Some races and some communities adhere closely to the median or average. For example, the English show little tendency to vary from the established average. In view of the place the English hold in the world, there is nothing in the present statistics to justify the denial that the middle course, as far as the distribution of nervous and mental disease is concerned, may be the characteristic of the people which attains the most power in the end.

The social value of such information as the statistics yield would, of course, be enhanced by comparison with additional information concerning the circumstances of residence of these races in this country. To draw any final deductions it would be necessary to know the circumstances of immigration, the causes of emigration, class of immigrants, localities settled in here, and nature of occupations followed.

For example, the statistics indicate that the Italians and Mexicans in the United States are at a low level of intelligence and unable to compete with, let us say, the Scotch or the Irish. But they give no information as to whether these people represent an average of Italians and Mexicans living at home, or are merely representatives of inferior groups of Italians and Mexicans who, for some reason or other, have come here.

In comparing the native-born with the foreign-born, particularly, it would be valuable to know about the circumstances of immigration. The number of foreign-born peoples classified is limited, by necessity, to four races: Italians, Scandinavian, Irish and German. As between them and the native-born of the same race, certain definite variations in the distribution of neuropsychiatric defects are noticeable. For example, practically all native-born were found to be more addicted to drugs than the foreign-born. Residence in this country seems to foster a drug inebriety or to convert alcoholic inebriety into drug inebriety. Similarly, there appears to be a decrease in the number of cases of insanity among foreigners after residence in this country. Final explanation of these facts, however, must await a fuller knowledge of the circumstances under which a particular group of foreigners came to this country.

\section{METHOD}

The present statistics record only those cases which were identified at recruiting depot posts and at camps, namely, at the military points of enrollment. They record diagnoses or identifications, irrespectively of the military disposition made of the cases. They do not take into account the men rejected by local boards. Thus they cannot determine the percentage of neuropsychiatric cases to the total number of men examined. Information of this character as far as draftees are concerned, may be obtained in the reports of the Provost Marshal-General, 
and in "Defects Found in Drafted Men." 2 The method used here is that of distribution averages solely. It begins with 69,394 fully classified cases found among volunteers and draftees (Chart 1 ). This total of cases was divided into nine distinct clinical groups, and the percentages assigned to each group indicate how that group stood in relation to the total of neuropsychiatric cases found. Thus of all neuropsychiatric cases found in the home forces, black and white, 31.5 per cent. were cases of mental deficiency. This percentage represents the distribution average. As such differences existed between white men and negroes, when the distribution average of the United States was

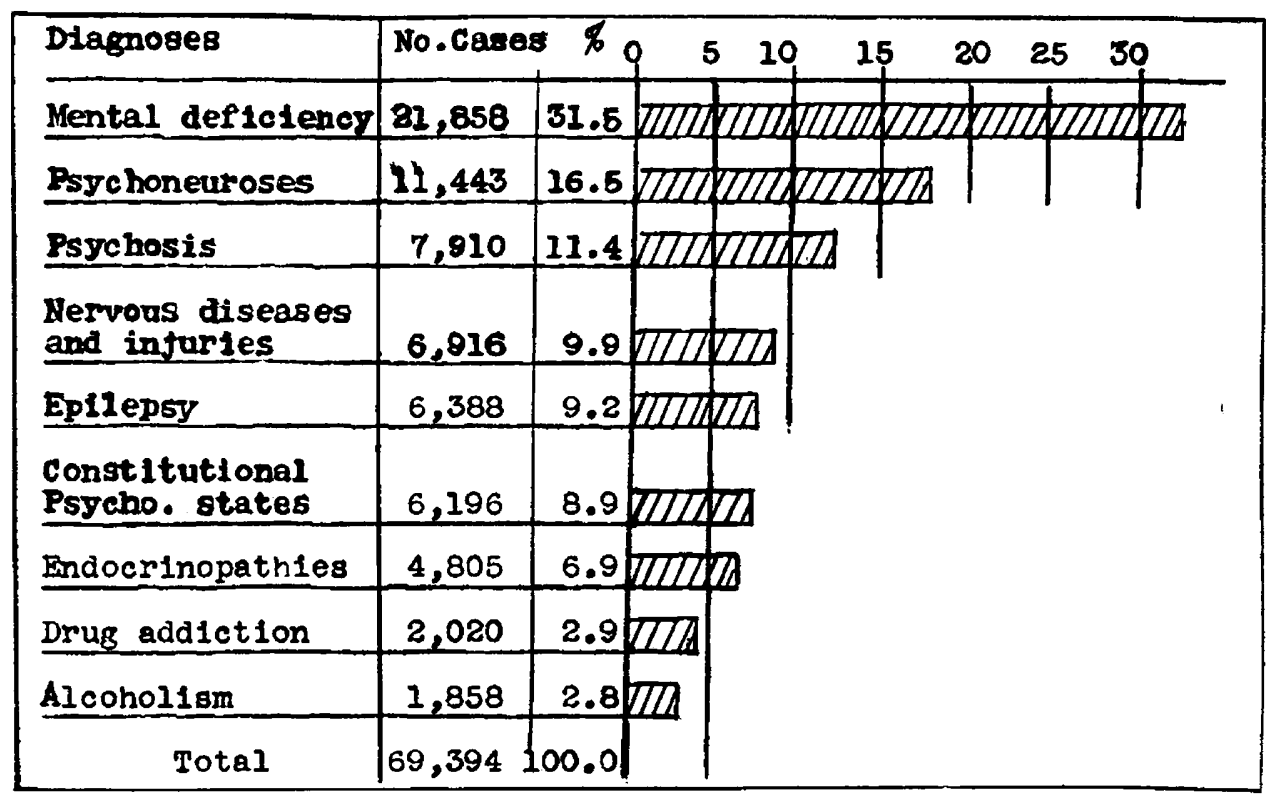

Chart 1.-Distribution of neuropsychiatric cases.

determined, it was determined separately for white and colored persons. By this method the average for mental defect in the United States was estimated from the distribution of mental defect among white persons and was found to be 29.2 per cent. A similar procedure was followed to determine the variations in the distribution of the various disease types found among the inhabitants of the different states and, as concerns the present article especially, among the members of certain foreign-born and native-born races. The total number of neuropsychiatric conditions found among a people, the Scotch, for example, was ascertained, and the percentage belonging to each clinical group

2. Love and Davenport: Defects Found in Drafted Men, Government Printing Office, Washington, D. C., 1919. 
was determined for the Scotch in the same way that it had been determined for the people of the United States as a whole. There was thus furnished a means of comparison between the distribution of each clinical group throughout the United States and the races which were classified. Startling variations were disclosed. This paper was written in the belief that these variations have something to offer toward the understanding of the characteristics of the different peoples concerned.

In interpreting the results two cautions should be kept in mind: First, that as all percentages are based on the total number of neuropsychiatric cases from each race, it is evident that when an excessive percentage is taken up by a single condition, the percentages of the other eight groups must be low, that is, a high rate in one group tends to lower the rate in all other groups.

It also should be noted that in reporting cases the examiners had to choose at times between two or more neuropsychiatric disorders. It is probable that constitutional defects were preferred to alcoholism or drug addiction. But this overlapping is not believed to have affected the rates to any great degree.

\section{CLINICAL CLASSIFICATION}

The graph (Chart 1) shows the nine clinical groups into which the whole material was divided. It is made up of all cases in which the information was sufficiently detailed to be classifiable, and the figures are only a little under the total number of diagnoses made.

Mental Deficiency.-No idiots reached the military posts, and so this group is made up of imbeciles, morons, those whose disease was on the borderlines and a small number in whom the degree of defect was not determined. About 90 per cent. of all those whose cases were identified were discharged from the service, and as the standard for discharge was fixed approximately at a mental age of 8 years, it is assumed that the bulk of the cases were at the 8-year-old level.

Psychoneuroses.-This group is composed of neurasthenia, hysteria, psychasthenia, stammering, enuresis, anxiety neurosis, traumatic cases and a few scattering and undiagnosed cases.

Psychoses.--In this group are included dementia praecox, manicdepressive insanity, general paresis and other psychoses associated with syphilis, mental deficiency and epilepsy.

Nervous Diseases and Injuries.-In this class are grouped the injuries of the nervous system, its organic diseases and such conditions as tremors, sciatica, tics, etc. Syphilis of the central nervous system was held responsible for nearly one half of these cases, and consequently a high distribution rate of this group in a people gives some 
indication of the frequency of syphilis in that people. If to them are added the psychosis due to syphilis (general paresis) and psychoses with cerebral syphilis from the preceding group the percentage of late nervous syphilis to the total of 69,394 cases would be approximately 3 per cent.

Epilepsy.-This includes both grand and petit mal attacks.

Constitutional Psychopathic States.-This group contains persons socially undependable as determined from personal examination and from past records classified into those with: inadequate personality, emotional instability, paranoid personality, criminalism, sexual psychopathy and a few other scattering forms. These persons are not feebleminded; on the contrary, they often have active intelligence, thus belonging to the groups of developed intelligence rather than to the mental deficiency group.

Endocrinopathies.-This group is much larger over the country as a whole than appears from the present statistics because under the names "effort syndrome," "cardiovascular" disturbances, etc., many cases fell exclusively to the cardiovascular examiners. The cases given here include those in which were symptoms of great nervousness, combined with definite lesions referable to the endocrine glands. In 93 per cent. of the cases the gland at fault was the thyroid.

Alcoholism and Drug Addiction.--Alcoholism in these statistics implies a chronic intoxication so profound that the person was, for the most part, beyond reconstruction for military purposes. Drug addiction, while allied to alcoholism as a form of inebriety, is subject to wide variation due to local conditions. It will be observed that the number of drug addicts and of alcoholics is practically the same. It should not be inferred, however, that these two disorders are of equal social importance, for that is far from true. The majority of intemperate men were accepted for service and made good. No medical record was kept of their habits. Records were kept only of the more or less permanently incapacitated alcoholic men. Quite the contrary was true of the drug addicts. They have always been looked on with disfavor by military authorities, and few were retained.

\section{MENTAL DEFECT THE PIVOTAL POINT}

Mental defect being the most widely distributed condition and the one most directly concerned with the question of general intelligence becomes naturally the pivotal point of the present discussion. It is assumed to be a distinct clinical entity, classifiable and distinct from insanity or any other of the different neuropsychiatric conditions.

It is the result of a failure of development of the mentality up to a capacity which, as we are dealing only with adults, we may call adult 
capacity. The normal of adult capacity has been roughly established by psychologic tests among civilized people. It is still unsettled whether or not this standard would be the same for primitive races as for cultured ones, that is, whether or not an average child of a savage, if from infancy it were given the same advantages as, let us say, the average French or English child, would develop into an adult with the average intelligence of a Frenchman or an Englishman. From the statistics which relate to two so-called primitive races, the African and the American Indian, it appears that the primitive could not under any present circumstances attain the average intelligence of cultured races. This appears to be so, not because there is any detailed information as to the potentiality of the primitive mind, but because mental deficiency is so profusely distributed among Africans and American Indians that their average intelligence must be inferior to that of average European intelligence.

At this point arises a question, and one that cannot be answered from the data on hand: What does excessive mental defect in a race mean? Is it a biologic condition marking the race as being in an early phase of development and establishing a level of intelligence more or less normal for the particular phase of evolutionary development in which the race finds itself, or does it mean that the race has been brought back to a regressive phase through the unrestricted interbreeding of mental defectives? That Caucasian strains can be reduced to low levels of intelligence we know from observation of communities in which the continual interbreeding of mental defectives has brought about that result. Is it possible that in a race we call primitive, like the negro race, a similar thing has occurred so that the backwardness is the result of some such racial setback?

The distribution percentage of mental defect is taken as an index of general intelligence, because when this distribution is excessive, the average intelligence can hardly fail to be lowered. It is lowered not only by the actual mental defectives, but by the number of dull people which the existence of mental defect implies, for it is estimated that for every case of mental defect of the 8-year-old mentality standard, there are at least ten cases of backward or retarded mentality.

An example will make this plain: Vermont ${ }^{2}$ showed among its draftees 30.90 mental defectives for every 1,000 men examined. What does this indicate about that community? As mental defect shows no great predilection for either sex, it means that had females been included in the draft restriction, the rate of 30.90 would have been maintained for both sexes in the given age period. As mental defect shows no special predilection for the age period from 20 to 30 , it means that this rate would maintain for the whole population at all ages. It would, therefore, apparently be safe to assume that there are at least 
thirty defectives per thousand in Vermont of the 8-year-old mentality type, and 300 per 1,000 of backward or retarded persons-persons of distinctly inferior intelligence. In other words, nearly one third of the whole population of that state is of a type to require some supervision and special educational facilities, and even then they cannot attain the average intelligence of cultured races,

In addition to the lowering of the general intelligence brought about by an overproportion of mental defectives plus the dullards who are always found with them, the outlook for the general intelligence is further impaired by the reduction in the chance of the appearance of persons of superior intelligence with the qualities of leaders.

When countries and especially when races are compared, the significance of a high ratio of distinctly inferior persons in a community becomes apparent. For example, the American Indian presents among his nervous and mental disorders a mental deficiency distribution rate of more than double, and the African a rate a little less than double, that of the distribution rate among white persons over the whole United States. This in itself is enough to explain the inability of the two races to compete with the average American. The Mexicans living in the United States present an even higher distribution rate for mental defect (66.9 per cent.), but concerning the Mexicans in general, in fact concerning all races which may have immigrated here within recent years, we can draw no such general conclusions as we can about the indigenous Indian and negro races. Concerning the foreign races which present a high distribution rate for mental defect, such as the Slavs (37 per cent.) and the Italians ( 32.7 per cent.), it can only be said that the ones living here now are distinctly below the average United States intelligence. It would be impossible to infer that these races at home present the same degree of mental inferiority; it may be that these countries sent us a high proportion of defectives and that these have intermarried.

Throughout the present material, mental deficiency shows significant correlations with the other neuropsychiatric conditions, and these correlations throw some light on the extent and quality of the intelligence of the people concerned.

As concerns psychoses or mental disorders, it might be assumed that these would be less likely to occur when there was a high rate for mental deficiency. With the exception of the toxic psychoses, the existence of a mental disease implies a developed intelligence, a kind of intelligence that would possess imagination, ideas, a certain quickness in mental processes. As is well known, distinct types of psychoses are practically unknown in childhood, the period before the intelligence is fully developed. The hypothesis that mental disease implies a developed intelligence and so would be less frequent among people in 
whom the intelligence is underdeveloped is borne out by the accompanying tables. Nineteen states exceeded (Table 1) the United States mental deficiency rate of 29.2 per cent., and showed among themselves an average of mental defect of 39.3 per cent. But the insanity rate

Table 1.-Distribution Rates in Nineteen States in Which the United United States Mental Deficiency Rate of 29.2 Per Cent. Was Exceeded

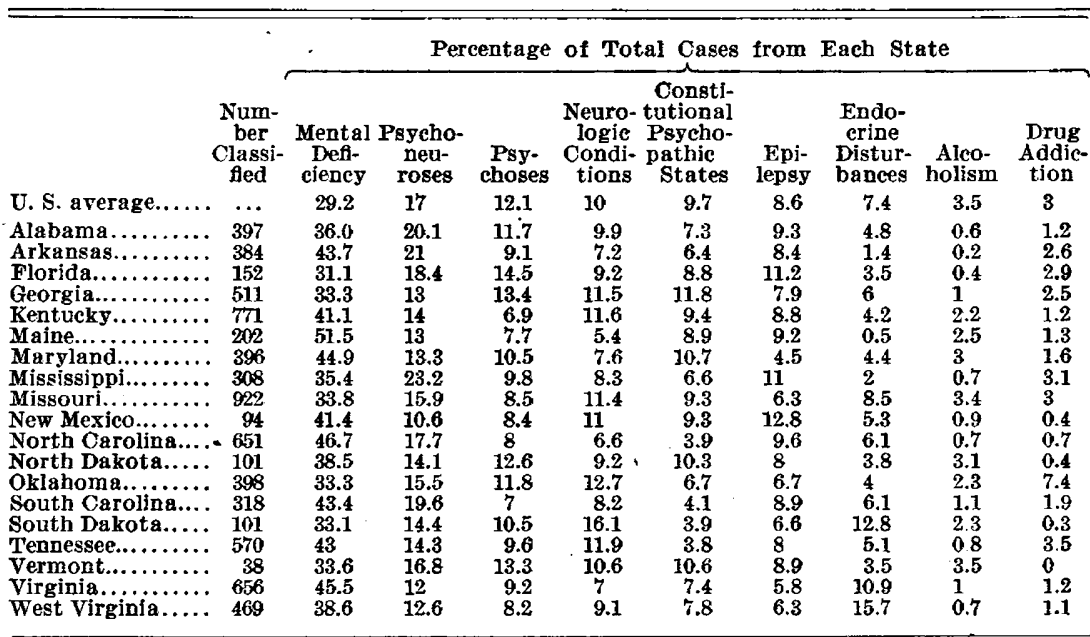

Table 2.-Distribution Rates in Five Native-Born Races in Which the United States Mental Deficiency Rate of 29.2 Per Cent. Was Exceeded

\begin{tabular}{|c|c|c|c|c|c|c|c|c|c|c|}
\hline & & \multicolumn{9}{|c|}{ Percentage of Total of Each Race } \\
\hline & $\begin{array}{l}\text { Num- } \\
\text { ber } \\
\text { Classi- } \\
\text { fied }\end{array}$ & $\begin{array}{c}\text { Mental } \\
\text { Defl- } \\
\text { ciency }\end{array}$ & $\begin{array}{c}\text { Psycho- } \\
\text { neu- } \\
\text { roses }\end{array}$ & $\begin{array}{c}\text { Psy- } \\
\text { choses }\end{array}$ & $\begin{array}{l}\text { Neuro- } \\
\text { logic } \\
\text { Condi- } \\
\text { tions }\end{array}$ & $\begin{array}{l}\text { Consti- } \\
\text { tutional } \\
\text { Psycho- } \\
\text { pathic } \\
\text { States }\end{array}$ & $\begin{array}{c}\text { Epi- } \\
\text { lepsy }\end{array}$ & $\begin{array}{l}\text { Endo- } \\
\text { crine } \\
\text { Distur- } \\
\text { bances }\end{array}$ & $\begin{array}{c}\text { Aleo- } \\
\text { holism }\end{array}$ & $\begin{array}{c}\text { Drug } \\
\text { Addie- } \\
\text { tion }\end{array}$ \\
\hline U. S. average...... & . $\ldots$ & 29.2 & 17 & 12.1 & 10 & 9.7 & 8.6 & 7.4 & 3.5 & 3 \\
\hline 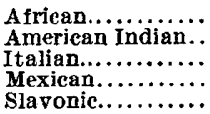 & $\begin{array}{r}8,406 \\
124 \\
2,456 \\
384 \\
2,488\end{array}$ & $\begin{array}{l}48.3 \\
62.9 \\
32.7 \\
66.9 \\
37\end{array}$ & $\begin{array}{r}13.1 \\
4.9 \\
18.1 \\
4.2 \\
15.3\end{array} \bullet$ & \begin{tabular}{r}
\multicolumn{1}{l}{6.6} \\
4 \\
9.7 \\
4.7 \\
14.4
\end{tabular} & $\begin{array}{l}9.5 \\
4 \\
7.8 \\
5.7 \\
7.3\end{array}$ & $\begin{array}{c}3.1 \\
8.9 \\
9.3 \\
3.9 \\
10\end{array}$ & $\begin{array}{r}13.3 \\
7.3 \\
12.9 \\
11.7 \\
6.6\end{array}$ & $\begin{array}{l}3.5 \\
2.4 \\
3.8 \\
3.4 \\
5.7\end{array}$ & $\begin{array}{l}0.3 \\
2.4 \\
0.6 \\
0 \\
\mathbf{3 . 1}\end{array}$ & $\begin{array}{l}2.3 \\
3.2 \\
5.3 \\
0.5 \\
1.2\end{array}$ \\
\hline
\end{tabular}

was below the United States rate in these nineteen states, being particularly depressed in the states with high rates for mental defect: Arkansas, Kentucky, Maine, New Mexico, North Carolina, Tennesee and Virginia. The same correlation holds true for the five native-born races (Table 2) which exceed the United States rate of 29.2 per cent. for mental defect (with the exception of the Slavonic), namely, the Africans, American Indians, Italians and Mexicans. 
The converse of this correlation between mental defect and insanity appears in twenty-five states (Table 3) which showed an increase in the insanity distribution rate. Of these, North Dakota alone showed an increase in the mental deficiency rate. The same relation holds true for eight of the fifteen classified native-born races which show an excess distribution of insanity (Table 6), with the exception of the Slavs. The distribution average of these nine races was 12.3 per cent. for psychoses and 21.7 per cent. for mental deficiency. An isolated example of the variations between mental deficiency and insanity is shown in the case of Florida. In that state the over average mental deficiency

TABle 3.-Distribution Rates in Twenty-Five States in Which the United States Rate of 12.1 Per Cent. Was Exceeded (Whites)

\begin{tabular}{|c|c|c|c|c|c|c|c|c|c|c|}
\hline & \multirow[b]{2}{*}{$\begin{array}{l}\text { Num- } \\
\text { ber } \\
\text { Classi- } \\
\text { fied }\end{array}$} & \multicolumn{9}{|c|}{ Percentage of Total Cases from Each State } \\
\hline & & $\begin{array}{l}\text { Psy* } \\
\text { choses }\end{array}$ & $\begin{array}{c}\text { Mental } \\
\text { Defl- } \\
\text { ciency }\end{array}$ & $\begin{array}{c}\text { Psycho- } \\
\text { neu- } \\
\text { roses }\end{array}$ & $\begin{array}{c}\text { Neuro- } \\
\text { logie } \\
\text { Condi- } \\
\text { tions }\end{array}$ & $\begin{array}{l}\text { Consti- } \\
\text { tutional } \\
\text { Psycho- } \\
\text { pathic } \\
\text { States }\end{array}$ & $\begin{array}{r}\text { Epi- } \\
\text { lepsy }\end{array}$ & $\begin{array}{l}\text { Endo- } \\
\text { crine } \\
\text { Distur- } \\
\text { bances }\end{array}$ & $\begin{array}{c}\text { Alco- } \\
\text { holism }\end{array}$ & $\begin{array}{l}\text { Drug } \\
\text { Addic- } \\
\text { tjon }\end{array}$ \\
\hline U. S. average...... & . $\ldots$ & 12.1 & 29.2 & 17 & 10 & 0.7 & 8.6 & 7.4 & 3.5 & 3 \\
\hline Arizona........... & 20 & 16.7 & 15 & 12.5 & 18.3 & 11.6 & 10.8 & 6.7 & 5 & 4.2 \\
\hline California.. & 297 & 17.4 & $\mathscr{2 0}$ & 16.7 & 12.2 & 12.7 & 7.7 & 2.7 & 6 & $\begin{array}{l}7.4 \\
3.3\end{array}$ \\
\hline Colorado......... & 70 & 14.4 & 28.4 & 18.2 & 10.7 & 9.5 & 11.8 & 6.4 & 2.1 & 2.1 \\
\hline Connecticut....... & 97 & 15.9 & 26.7 & 17.8 & 7.7 & 10.3 & 10.6 & 3.1 & 5.7 & 2.9 \\
\hline Florida........... & 71 & 14.5 & 31.4 & 18.4 & 9.2 & 8.8 & 11.2 & 3.5 & 0.4 & 2.9 \\
\hline Georgia........... & . 205 & 13.4 & 33.3 & 13 & 11.5 & 11.8 & 7.9 & 6 & 1 & 2.5 \\
\hline Idaho........ & . $\quad 42$ & 25.4 & 26.7 & 10.3 & 8.5 & 6.7 & 7.9 & 14.5 & 0.1 & 0 \\
\hline Illinois....... & . 546 & 13.8 & 19.9 & 20.7 & 10.7 & 9.1 & 8.3 & 9.8 & 7 & 1.5 \\
\hline Iowa............. & 155 & 16.4 & 25.3 & 17.8 & 9.9 & 9.3 & 8.4 & 8.2 & 2.2 & 2.6 \\
\hline Massachusetts.... & . 224 & 14.4 & 25.7 & 18.1 & 2.7 & 12.2 & 10.4 & 1.7 & 8.8 & 2.7 \\
\hline Michigan......... & . 288 & 13.5 & 29.2 & 12 & 11 & 11.7 & 8.6 & 11.2 & 2.3 & 1.1 \\
\hline Minnesota......... & 165 & 14 & 22.2 & 19.5 & 10.9 & 7.1 & 7.8 & 12 & 4.9 & 2.2 \\
\hline Montana............ & 56 & 20.8 & 16.7 & 16 & 11.2 & 8.9 & 11.9 & 7.8 & 3.7 & 3.7 \\
\hline Nebraska......... & 77 & 15.5 & 25.1 & 14.7 & 12.9 & 9.4 & 7.6 & 10.6 & 1.8 & 2.6 \\
\hline Nevada........... & 11 & 18.3 & 18.3 & 11.7 & 18.3 & 6.7 & 8.3 & 1.7 & 18.3 & 1.7 \\
\hline New Jersey. & . 191 & 13.4 & 27.5 & 16.6 & 6.8 & 11.2 & 12.6 & 5.7 & 3.6 & 3 \\
\hline North Dakota......... & . 33 & 12.6 & 38.5 & 14.1 & 9.2 & 10.3 & 8 & 3.8 & 3.1 & 0.4 \\
\hline Ohio........................ & . 427 & 13.3 & 23.9 & 19.7 & 10.9 & 8.6 & 7.7 & 12.8 & 2.8 & 2.7 \\
\hline Oregon..... & 60 & 19.7 & 18.1 & 19.1 & 8.9 & 16.5 & 9.5 & 2.3 & 0.3 & 2.6 \\
\hline Tex8s...... & 285 & 17.5 & 25.5 & 14.8 & 6 & 8.8 & 13.5 & 5.3 & 1.4 & 4.1 \\
\hline Utah..... & 28 & 18.6 & 20.5 & $\begin{array}{l}14.0 \\
19.2\end{array}$ & 12.3 & 12.6 & 7.9 & 4 & 3.3 & 7.9 \\
\hline Vermont.......... & 15 & 13.3 & 33.6 & 16.8 & 10.6 & 10.6 & 8.9 & 3.5 & 3.5 & 0 \\
\hline Washington....... & 78 & 17.7 & 28.6 & 14 & 8.2 & 9.5 & 7.5 & 9.3 & 1.4 & 6.8 \\
\hline Wisconsin........... & 170 & 12.6 & 27 & $\begin{array}{l}14 \\
19.2\end{array}$ & 11.6 & 6.3 & 6.8 & 12.6 & 3.9 & 0.7 \\
\hline Dist. Columbia.... & $\quad 32$ & 19.9 & 16.1 & 23.6 & 14.3 & 8.7 & 6.2 & 6.2 & 3.7 & 2.5 \\
\hline
\end{tabular}

rate concerns the white people only-among Florida negroes it was 11.5 per cent., or 17.7 per cent., below the United States rate for white people. But the Florida negroes show an insanity rate of 13.8 per cent., which exceeds the United States distribution for insanity in negroes by 7.3 per cent.

Between mental deficiency and alcoholism there seems to exist a very definite antagonism in that the two conditions do not exist in greatest abundance in the same communities and among the same kind of people. When the rate for one rises, the rate for the other falls. Of the nineteen states (Table 1) with an excess of mental deficiency, not one has an excess distribution of alcoholism, and in these nineteen states the average for alcoholism is 1.6 per cent. as compared with 
3.5 per cent., the United States average. Conversely, seventeen states exceeded the United States average for alcoholism by 3.5 per cent. A similar antagonism is observed in the different races.

None of the five native-born races (Table 2) which exceed the United States rate for mental deficiency attains the United States alcoholic rate of 3.5 per cent. Conversely, none of the native-born races-the Hebrew, Irish, Scotch, Greek and Spanish-which exceeds the United States alcohol rate, attains the United States mental deficiency rate of 29.2. Similar conditions prevail in the foreign-born races classified.

TABLE 4.-Distribution Rates of Neuropsychiatric Conditions Among Four Different Races, with Comparisons Between the Native-Born AND THE Foreign-Born

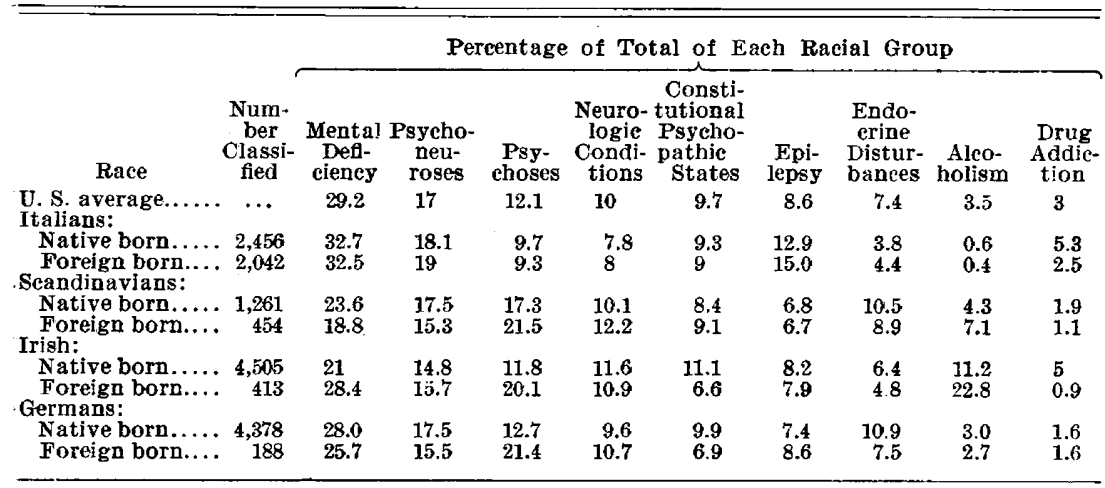

In the states in which the distribution of mental deficiency is over average, there is practically no change in the rate for epilepsy; in the races a slight increase in the rate for epilepsy occurs. As concerns the psychoneuroses, states and races with plus mental deficiency show a slight decrease. With some exceptions, constitutionally psychopathic states tended to be below the United States average in both the states and the races which showed an excess of mental deficiency. It would, therefore, seem that an excess of mental deficiency in a people assures an amount of alcoholism, insanity and psychopathic states below the average, and conversely, that when these conditions are in excess mental deficiency recedes.

The foregoing variations apply to the fifteen classified races in the United States as shown in Table 6. Table 4 shows four of them, divided as was possible, into native-born and foreign-born.

MENTAL CONDITION OF VARIOUS RACES IN THE UNITED STATES

African Race.-(Number classified, 8,340.) The most striking characteristic of the negro is the wide distribution of mental defect 
(48.3 per cent.) and the low distribution of alcoholism. In negroes the mental deficiency rate exceeded the United States rate for white people by 19.1. The southern states are high in mental defect, but the negro cannot be held entirely responsible for this as in many southern states the mental defect for white people exceeds that for negroes, as shown in Table $5 .^{3}$

It will be observed that in these southern states the average mental deficiency rate for the white population is considerably higher than the United States average for white people, 29.2 per cent., and that the average rate for the negro is considerably below the United States average for the negro, 48.3 per cent. In Florida, Georgia, Kentucky, North and South Carolina and West Virginia there are proportionately more white than colored mental defectives.

TABLE 5.-Mental Deficiency Distribution Rates for White and for Brack Population in Twelve Southern States

\begin{tabular}{|c|c|c|}
\hline & Negroes & Whites \\
\hline 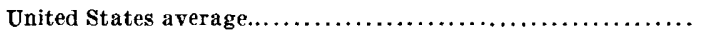 & 48.3 & 29.2 \\
\hline 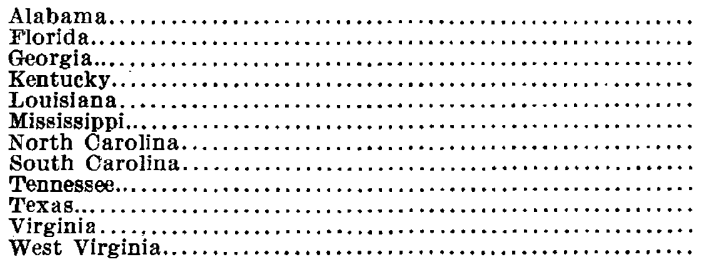 & $\begin{array}{l}66.4 \\
11.5 \\
31.7 \\
38.5 \\
48.3 \\
44.6 \\
40.8 \\
40 \\
71.8 \\
33.4 \\
48.6 \\
37.5\end{array}$ & $\begin{array}{l}36 \\
31.1 \\
33.3 \\
41.1 \\
28.8 \\
35.4 \\
46.7 \\
43.4 \\
43 \\
25 \\
45.5 \\
38.6\end{array}$ \\
\hline
\end{tabular}

Some students seem to think that the backward condition of the negro is the result of his environmental conditions; that if he were given opportunity he could approximate the Caucasian standard of mentality. The present statistics do not bear out such an opinion."

It is true that in certain northern states the mental deficiency rate for negroes is much lower than in the south-indeed, in New Jersey it is lower for negroes (21 per cent.) than for white people ( 27.5 per

3. No cases of mental defect among negroes, or too few to classify, were found in California, North Dakota, South Dakota, Oregon, Utah, Vermont, Washington and Wyoming. This simply means a small negro population as these states together gave a total of forty-five psychiatric cases among the negroes.

4. According to Trabue, intelligence rating taken of drafted negroes from Louisiana and Mississippi, and of white men from Illinois, Wisconsin and Minnesota, showed that only 0.2 per cent. of the negroes from Louisiana and 0.5 per cent. of the negroes from Mississippi were graded as superior, while 10.7 per cent. of the white men had this standing. At the other extreme only 7.4 per cent. of the white men had a grade of inferior or very inferior, while 52.9 per cent. of the Mississippi negroes, and 63.3 per cent. of the Louisiana negroes, had this low grade. Natural History 9: No. 6, 1919. 
cent.). The apprentice system for slaves prevailed in New Jersey until 1863. This system provided supervision and care and may help to explain the present superior quality of negroes in New Jersey. Also one must bear in mind that mental defect is a social weed, tending to spread; one must also bear in mind the important factor of migration. The brighter and more enterprising members of rural communities have for years been pushing out for the large cities, leaving the dullards and defectives on the plantations and farms. It seems, therefore, possible that the higher mentality of northern negroes is not the result of environmental conditions, but is due to the fact that they came of better stock in the first place, the northern negro population consisting of slaves who had had wit enough to escape, or servants selected with greater care: that the low mentality of the southern negroes is due to their staying together and interbreeding.

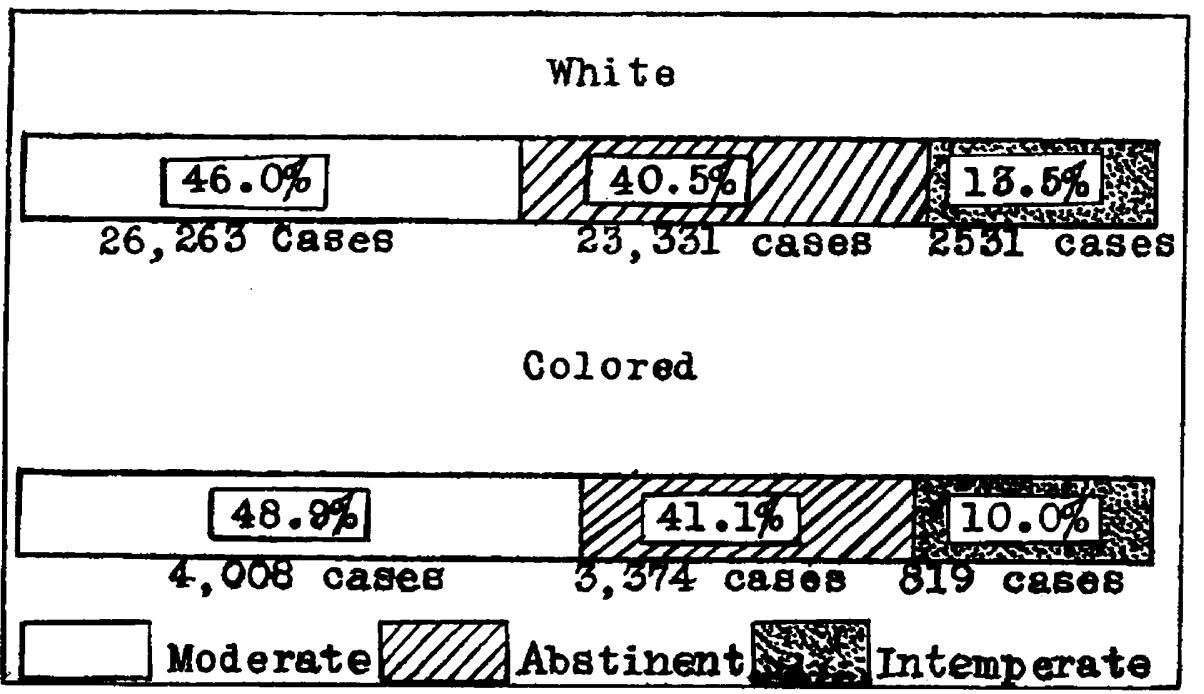

Chart 2.-Alcoholic habits of white and colored neuropsychiatric patients.

In contrast to the high distribution of mental deficiency among the neuropsychiatric conditions of negroes, alcoholism among them practically did not exist. There were only twenty-nine cases in all. This absence of the disastrous effects of intemperance contradicts the current belief that the ravages, which result from the abuse of alcohol, are particularly severe among primitive races. Chart 2 shows the percentage of distribution as to the use of alcohol among white and black persons with neuropsychiatric conditions. It will be observed that the negroes have a slight advantage. It would seem, therefore, that the negro can be practically as intemperate as the white man, without paying the same penalty for it. On the other hand, he is 
much more susceptible to venereal diseases; 57.8 per cent. of all negroes gave a history of venereal infections of some sort, while only 22.3 per cent. of white people gave such a history. In view of this great disparity, and since the white people actually drank more than the negroes, it would seem that some modification would have to be made in our views of the prime importance of alcohol as a factor in the spread of venereal diseases.

A similar, though less marked resistance to the involvement of the central nervous system by syphilis is shown by the negro. Among neuropsychiatric cases the history of preceding syphilis was more than three times as frequent in negroes as in white persons, but the involvement of the central nervous system by that disease was about equal in the two classes.

Table 6.-Distribution Rates of Neuropsychiatric Cases Among Fifteen Classified Native-Born Races

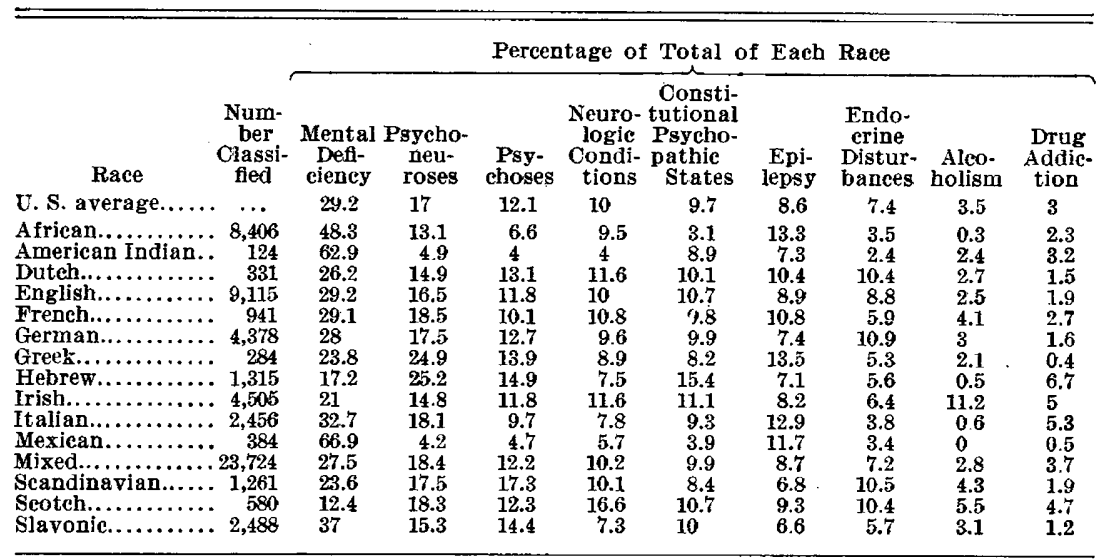

The correlation of mental deficiency with other neuropsychiatric conditions gives important information, both as to mental deficiency in relation to the United States average for white persons and in relation to its average distribution among the negroes exclusively.

Of the first, Table 6 shows that, with the exception of mental deficiency and epilepsy, the negro falls below the United States average for all neuropsychiatric conditions. The negro falls much farther below both white and negro average for all these conditions in seven states in which he exceeds the negro United States rate for mental defectives. An undue distribution of mental defect inevitably necessitates a falling off in other neuropsychiatric conditions; but, as stated before, when mental defect is above the average, the falling off affects 
especially mental diseases, constitutional psychopathic states and inebriety.

The Provost Marshal-General in his final report credits the negro draftee with a somewhat better physique than the white. The present statistics bear this out as far as the two neuropsychiatric conditions which have a definite physical basis are concerned, namely, neurologic conditions and endocrine disturbances. The particular distribution of neuropsychiatric defects among negroes points them out clearly as a primitive race. Physically, they may be above the average of the people with whom they associate, but they are far below that average in mental capacity.

It will hardly be possible to determine what better social opportunities and education will do for negroes before the present high incidence of mental defect among them is reduced.

American Indian.-(Number classified, 124.) The American Indian, or Amerindian, as H. G. Wells calls him, is primitive like the negro, and exceeds even him in mental deficiency. He is not as much below the United States average in alcoholism or drugs as the negro, and is somewhat below the negro in epilepsy, as indeed he is below the United States average in that disease. In other conditions, namely, neurologic, psychoses, psychoneuroses, endocrine and constitutional psychopathic states, he is far below the United States average. His high mental deficiency percentage leaves little room for anything else. The small number of American Indians classified should be borne in mind when these statistics are considered.

Dutch.-(Number classified, 331.) The Dutch are close to the United States average in all groups. The indications are that they ingest more alcohol than drugs, but in both they fall below the United States averages. They have a few less neuroses and a few more of the other classified disorders.

English.-(Number classified, 9,115.) The English, like the Dutch, approximate the United States average in all groups. They appear more inclined to drink than to take drugs, and to have a slight excess of epilepsy, endocrine troubles and constitutional psychopathic states. They just reach the United States average for mental defect.

French.-(Number classified, 941.) The French show rather a high distribution of inebriety, being considerably above the average in alcoholism, and only a little below it in drug addiction, their total percentage of inebriety distribution being 6.8 per cent. as compared with 4.4 per cent. for the English, and 4.6 per cent. for the Germans. They also exceed the average in the number of cases of psychoneuroses, neurologic conditions, epilepsy-and by 0.1 per cent. constitutional 
psychopathic states. They are considerably below the average in endocrine disease and are at the United States average for mental defect. The excess of inebriety in the French may surprise many as the French are said to be a wine-drinking people, and it is a common belief wine-drinking people do not suffer from alcoholism. As a matter of fact, alcoholism depends on the actual amount of alcohol imbibed, rather than on the form in which it is taken. If enough wine or beer or any other beverage with comparatively low alcohol content is taken, a person becomes alcoholic. As far as France is concerned, large quantities of spirits are consumed in that country in addition to wines, and it may be that this custom persists among the French who live in this country.

The Native-Born German.-(Number classified, 4,378.) In spite of his reputed beer-drinking custom, the native-born German, according to the statistics, fails to reach the United States average in alcoholism and is not much given to drugs. On the other hand, he exceeds slightly the United States average in psychoses, neuroses and constitutional psychopathic states, and in endocrine diseases by 3.5 per cent. $\mathrm{He}$ is slightly below the United States average in mental defect.

The Foreign-Born German-_(Number classified, 188.) The foreign-born German shows a much higher rate for insanity than the native-born, and a considerably higher rate in endocrine diseases. Mental defect, on the other hand, is considerably less.

Greeks.-(Number classified, 284.) The Greeks are very low in inebriety, especially as concerns drugs, but exceed the United States average in epilepsy, psychoses and psychoneuroses, an excess particularly noticeable in epilepsy and psychoneuroses. They are well below the average in mental defect and constitutional psychopathic states.

Jews.-(Number classified, 1,315.) The American Jew shows a striking contrast in his habits of inebriety as far as the choice of alcohol and drugs is concerned. The number of Hebrew alcoholic patients is almost negligible, while the percentage of drug addicts is more than double the United States rate. The percentage of neurologic conditions, epilepsy, endocrine diseases and mental deficiency among Jews is also low. The low percentage of mental defect is particularly striking, the only classified races which show less being the Scotch and the Welch. The Jew exceeds, on the other hand, the average representation in the conditions characterized by emotional instability. The percentage of insanity among Jews is nearly 2 per cent. above the United States average and is very much above it for psychoneuroses and the constitutional psychopathic states. 
Native-Born Irish--(Number classified, 4,505.) The native-born Irish show the most pronounced tendency to inebriety of any neuropsychiatric group, and their intemperance relates to both alcohol and drugs. Inebriety constitutes 16.2 per cent. of all their neuropsychiatric disorders. Approximately one sixteenth of all the neuropsychiatric cases being found among the native-born Irish, more than one fifth of all patients with alcoholism were identified as native-born Irish by the neuropsychiatric examiners and more than one sixth of all patients with drug addiction. With the exception of inebriety, epilepsy and constitutional psychopathic states, they sink below all United States averages. They are so far below this average in mental defect that they confirm the general law of the incompatibility of alcoholism and mental defect. They also furnish an interesting example of a high distribution of alcoholism with an under average of mental disease. It would seem that if alcoholism were an important cause of insanity, one would find an excess of insanity instead of an under average in a people so given to alcoholic intemperance as these people are. But in this connection it should be remembered that drafted men wert too young to develop alcoholic insanity and also that alcoholic insanity among the Irish is more common in women than in men.

The Irish offer an interesting comparison with the native-born English. There are 11.8 per cent. more cases of inebriety among the Irish and 8.2 per cent. less cases of mental defect. The excess of alcoholism and the lesser amount of mental defect would indicate that they are a livelier, more excitable race than the English, which is borne out by their having a slight excess of constitutional psychopaths as compared with the English.

Foreign-Born Irish--(Number classified, 413.) The difference between the native-born and foreign-born Irish in regard to nervous and mental diseases is that among those born in this country the distribution rate of mental defect is nearly 7 per cent. more than among the foreign-born, and among them also there is a higher distribution rate of constitutional psychopathic states and of endocrine disturbances. The average for insanity and inebriety, however, is lower. These are nearly 8 per cent. less in the distribution of mental disease among those born here. Inebriety changes both in extent and in its own distribution. There is a lessened total of inebriety of 6.4 per cent. among the native-born, and even a greater falling off in the distribution rate of alcoholism. Nearly one half of the decrease in alcoholism is accounted for by an increase in drug addiction among the native-born. It would seem at first sight that this lowering of the distribution rate for insanity is to be connected with the lowering of the rate of alcoholism, but it should be observed that a similar decrease in the distribution 
of insanity occurs in the Germans with a very minor decrease in alcoholism, and a smaller decrease in insanity among Scandinavians with a larger decrease in the rate of alcoholism.

Also, as far as the Irish are concerned, the material increase in mental defect and in constitutional psychopathic states should be noted.

Native-Born Italians.-(Number classified, 2,456.) The nativeborn Italians present a distribution of neuropsychiatric disorders which indicate a sluggish, backward mentality. As drug addicts they rank next to the Jews, and, like the Jews, are little given to alcoholic inebriety. Some races, such as the Jewish and the Irish, seem to be able to surpass the average in drug inebriety, and still, through the low percentage of other disorders which indicate racial backwardness, retain the characteristics of nimble-minded people. For example, the Irish, while they are excessive drug users, are more given to intemperance in alcohol than in drugs; and of the two, alcoholic intemperance is indicative of more active mentality than is the secret and solitary use of drugs. Both the Irish and Jews, while exceeding the average in the use of drugs, are far below it in mental defect. But the Italians make the poorer choice for the satisfaction of their inebriate tendencies, and in addition to that, show their racial backwardness by a preponderance of those other disorders which must be accepted as indicative of inferiority. In mental defect the native-born Italians exceed the United States average by 3.5 per cent., and in epilepsy they exceed the United States average by 4.3 per cent. In respect to the distribution of neuropsychiatric defect in general, they manifest a remarkable correlation with the two primitive races, the African and the Amerindians. All three have an excess of mental deficiency and are below the average in those disorders which indicate a developed mentality, namely, mental diseases and constitutional psychopathies. All are low in endocrine disturbances. Both the negroes and the Amerindians use drugs more than alcohol, and the negroes, like the Italians, have an excess of cases of epilepsy.

Foreign-Born Italians. - The foreign-born Italian shows so little variation from the native-born in the distribution of neuropsychiatric disorders that it seems that being brought up in this country has little effect on him in that respect. The rate for epilepsy is somewhat higher among the foreign-born, but, with the single exception of drug taking, the Italian who comes here is not much better and not much worse off than the one born here. Drug addiction is substantially more frequent among the native-born, as in fact it is among all the native-born foreign races except the German.

Mexicans.-(Number classified, 384.) Of all races classified, the Mexican stands first in mental defect, the rate being 66.9 per cent. 
It exceeds that of the Africans and Amerindians. With the single exception of epilepsy, they are below the United States average in every other neuropsychiatric group. They seem to be swamped in their own dulness, and they cannot develop, to any great extent, any of the disorders which indicate an active or emotional intelligence. There was not a single alcoholic person among those examined and onily two drug addicts, as contrasted with forty-five epileptic patients and 257 mentally defective. One would hardly expect that a race so slothful as the enormous amount of mental defect found among them make the Mexicans appear to be, would be a drinking people. But it is rather surprising that they are so free from drug addiction. Mexico is said to be one of the points from which opium (and its derivatives) is smuggled into this country, and one would naturally think that the Mexicans themselves would become addicted to the use of it.

The Mixed Race.-(Number classified, 27,724.) The mixed races include those whose ancestors were of different races. This group, of course, includes many "Americans." The large number in it (one third of the total number of cases) makes this group fundamentally important in the establishment of the United States average.

Scandinavians.-(Number classified, 1,261.) Native-born Scandinavians (Norwegians, Danes, Swedes, Icelanders) show an excess of inebriety-alcohol inebriety preponderating-mental and endocrine disturbances. They exceed, but by a small fraction only, the United States average of neurologic disorders and neuroses. They are well below the average in mental defect and, almost as a corollary of this, in epilepsy.

Foreign-Born Scandinavians.-(Number classified, 454.) The foreign-born Scandinavians show much less mental deficiency than those born here, and, strangely enough, less endocrine disturbance. On the other hand, they show an excess distribution of alcoholism and insanity as compared with the native-born.

The Scotch.-(Number classified, 580.) The Scotch exceed the United States average in all groups except that of mental deficiency. The mental deficiency rate, 16.8 per cent., is lower than that of any race, being below the United States average. This bears out the reputation of the Scotch for intellectual superiority. The inebriety is high, but as in all races which have a low mental deficiency rate, alcoholism exceeds drug taking.

The Slavs.-(Bohemians, Bosnians, Croatians, Dalmatians, Herzegovinians, Montenegrins, Moravians, Poles, Russians, Ruthenians, Serbians, Slovaks and Slovenians. Number classified, 2,488.) The Slavs have a high mental deficiency rate in spite of which their inebriety 
is alcoholic rather than narcotic, although both varieties are below the United States average. The comparative infrequency of epilepsy is worthy of remark, especially in view of the high rate of mental deficiency. In spite also of the sluggishness indicated by the excess of mental deficiency, they have an emotional sphere of some activity, as is shown by the excess of psychoses among them. 